\title{
Evaluation of Bio-control Agents against Macrophomina phaseolina Causing Root and Stem Rot Disease of Sesamum
}

\author{
Jainpal Rathore ${ }^{1 *}$, K. N. Gupta ${ }^{1}$, Babli Verma ${ }^{2}$ and Gunnjeet Kaur ${ }^{3}$ \\ ${ }^{1}$ Department of Plant Pathology, Jawaharlal Nehru Krishi Viswavidlaya, \\ Jabalpur Madhya Pradesh-482004 \\ ${ }^{2}$ Department of Plant Pathology, Rajmata Vijayaraje Scindia Krishi Vishwa Vidyalaya, \\ Gwalior, Madhya Pradesh-474002 \\ ${ }^{3}$ School of agricultural science Dr KN Modi University Newai Rajasthan -304021 \\ *Corresponding author
}

\section{Keywords}

Sesame,

M. phaseolina,

T. viride,

P.fluorescens

Article Info

Accepted:

07 August 2020

Available Online:

10 September 2020

\begin{abstract}
A B S T R A C T
Sesame (Sesamum indicum L.) is aprimitive oilseed crops cultivated in semi-arid Tropics and sub tropics regions in India. Macrophomina phaseolina a soil borne fungus cause root and stem rot in sesame crop and pathogen attacks plant at all growth stages. Due to soil borne nature practically no effective field control and no source of resistant is available. A field experiment was conducted with twenty cultivars of sesame during kharif sesame 2017. Trichoderma viride and Pseudomonas fluorescens was evaluated in vivo and in vitro, to assess their antagonistic potential against $M$. phaseolina causing root and stem rot of sesame. Treatment $\left(\mathrm{T}_{5}\right.$-Seed treatment $T$. viride $+P$. fluorescens @ $10 \mathrm{~g} / \mathrm{kg}+$ Soil application of $P$. fluorescens @ $2.5 \mathrm{~kg} / \mathrm{ha}+T$. viride @ $2.5 \mathrm{~kg} / \mathrm{ha}$ enriched in $100 \mathrm{~kg}$ of FYM + Oil cake) @ $250 \mathrm{~kg} / \mathrm{ha}$ at sowing $)$ and Treatment $\left(\mathrm{T}_{3}\right.$-Seed treatment T. viride @ $10 \mathrm{~g} / \mathrm{kg}+$ soil application of T. viride @ $2.5 \mathrm{~kg} / \mathrm{ha}$ enriched in $100 \mathrm{~kg}$ of FYM + Oil cake) @ $250 \mathrm{~kg} / \mathrm{ha}$ at sowing) were found highly effective reducing the disease intensity $(12.3 \%, 14.0 \%)$ as compared to control (37.5\%). The sesame cultivars TKG$306(9.23 \%)$, TKG-21(10.0\%) were found resistant to root and stem rot disease.
\end{abstract}

\section{Introduction}

Sesame (Sesamum indicum L.) is the oldest among the oilseeds crops cultivated in semiarid tropics and sub tropics to temperate regions in India. Sesame which was originated in Africa is probably the most ancient oil seed plant cultivated in many parts of the world. Myanmar, India, China are the world's largest producers of sesame in the major sesame growing states are Uttar Pradesh, Rajasthan, Madhya Pradesh Chhattisgarh, Andhra Pradesh, Maharashtra, Gujarat, Tamil Nadu, West Wangal and Orissa Uttar Pradesh, Rajasthan, Madhya Pradesh or Chhattisgarh and contribute about half of the total sesame production of the country. However, a distressing feature is that the productivity of sesame in these states is very low. The main reason for low 
productivity of this crop is due to the attack of various weather factors and diseases, such as root and stem rot (Macrophomina phaseolina), Alternaria leaf spot (Alternaria sesame), Bacterial blight (Xanthomonas campestris pv. sesame), Powdery mildew (Erysiphe cichoracearum), Cercospora leaf spot (Cercospora sesame) and phyllody (Mycoplasma) Gupta et al., (2018). Root and stem rot caused by (M. phaseolina) affects severely at all the stages of the crop growth in the country it is grown in 17.14 lakh hactares area with production of 7.84 lakh tonnes and productivity of $457 \mathrm{~kg} / \mathrm{ha}$ during 2016 (Anon, 2017).Stem and root rot is caused by ( $M$. phaseolina) is one of the important diseases of this crop all over the world (Rajput et al., 1998; Dinakaran and Mohammed, 2001). It is very serious and destructive in all sesame growing areas and cause $5-100 \%$ yield loss and $57 \%$ yield loss at about $40 \%$ of disease incidence (Vyas, 1981; Maiti et al., 1988). The pathogen attacks root stem, leaf, pod and seeds (Mukharji and bhasin, 1986). The most common symptoms of the disease is sudden wilting of growing plant mainly after the flowering stage, stem portion near the ground level show dark brown and dark black lesion at the collar region show shreding and to destroy the vascular bundles by causing the plant death. Stem portion can be easily pulled out leaving the rotten rot portion in the soil (Avila et al., 1999). Macrophomina phaseolina is a seed and soil borne pathogen causing root and stem rot on sesame crops. The disease is very important as infection occurs from seed germination and emergence to adult stage. $M$. phaseolina is an important phytho pathogen distributed worldwide and causes charcoal rot on more than 500 plant species (Das et al., 2008). It is a mithosporic 2 fungal species (Menezes, 1993). It is a member of Phylum- Deteromycetes, ClassCoelomycetes, Order- Sphaeropsidales, and Family Sphaeropsidaceae. Pycnidia are 100$200 \mu \mathrm{m}$ in diameter, dark brown to greyish, becoming black with age, globose or flattened globose, membranous to sub carbonaceous with an inconspicuous or definite truncate ostiole. The pycnida bear simple, rod-shaped conidiophores, 10-15 $\mu \mathrm{m}$ long. Conidia are 14-33 × 6-12 $\mu \mathrm{m}$ in diameter, single celled, hyaline, and elliptic or oval. The pycniospores are elliptical, thin walled, hyaline, and measure $10-42$ x 6-10 $\mu \mathrm{m}$. Micro sclerotia of fungus are jet black in colour and appear smooth and round to oblong or irregular. Colonies in culture range in colour from white to brown or gray and darken with age. Hyphal branches generally form at right angles to parent hyphae, but branching is also common at acute angles. The fungus is greatly influenced by environmental factors and produces the pycnidia when the atmospheric temperature ranges of $25^{\circ} \mathrm{C}$ to $35^{\circ} \mathrm{C}$. The fungus survives in the form of sclerotia in soil and crop residues and also been reported to be seed born (Maiti et al., 1988). The available literature revealed that not much research work is carried out on sesame disease in Madhya Pradesh particularly on root and stem rot.

\section{Materials and Methods}

The present investigation, all the experiments were carried out during kharif 2017 in the Department of Plant Pathology and experimental area of PC Unit, AICRP Sesame and Niger, JNKVV, Jabalpur (Madhya Pradesh). For all laboratory experimental studies Corning and Borosil glasswares were used. The glass wares were kept for $24 \mathrm{hrs}$ in cleaning solution containing $60 \mathrm{~g}$ of potassium dichromate $\left(\mathrm{K}_{2} \mathrm{Cr}_{2} \mathrm{O}_{7}\right), 60 \mathrm{ml}$ of concentrated sulphuric acid $\left(\mathrm{H}_{2} \mathrm{SO}_{4}\right)$ in 1000 $\mathrm{ml}$ of water and were washed with detergent powder followed by washing in running tap water and then finally rinsed with distilled water. All the glasswares were sterilized in hot air oven at $160^{\circ} \mathrm{C}$ for two hrs. Sterilization of both solid and liquid media was done by 
autoclaving at $1.1 \mathrm{~kg} / \mathrm{cm}^{2}\left(121.6^{0} \mathrm{C}\right)$ pressure for 20 minutes for all the laboratory studies. The earthen pots were sterilized by dipping them in 10 per cent formaldehyde solution for 5 minutes.

Two bio agents viz. Trichoderma viride and bacterial bio-gents Pseudomonas fluorescens and its combination tested against ( $M$. phaseolina) by using dual culture technique (Sagar and Sugha, 1997). This test was conducted to evaluate the effect of biocontrol agent's viz. Trichoderma viride and Pseudomonas fluorescens against the growth and sclerotia formation of the pathogen $(M$. phaseolina) in in vitro. Dual culture technique was used to see the effect of bio control agents in which culture discs of $5 \mathrm{~mm}$ diameter of both antagonists and pathogen was cut from 7 days old culture using sterilized cork borer. A disc of pathogen culture was placed in plate poured with PDA opposite to antagonist at a distance $6 \mathrm{~cm}$. In control plate PDA disc were used in place of antagonistic culture. The plates were incubated at $27 \pm 20^{\circ} \mathrm{C}$. The radial growth of the pathogen was measured after five days. Sclerotia from 10 microscopic fields $(100 \mathrm{x})$ were observed at the interaction zone between the bio-agent and ( $M$. phaseolina). Ten sclerotia from each of the field were measured by micrometry. The per cent inhibition was calculated as suggested by Vincent (1947).

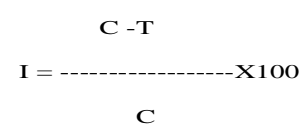

$\mathrm{I}=$ Per cent growth inhibition

$\mathrm{C}=$ Colony diameter in control $(\mathrm{mm})$

$\mathrm{T}=$ Colony diameter in respective treatment (mm)

This test was conducted to evaluate the most effective bio control agent under field condition, in which various bio control agents was used as seed treatment with recommended dose (Table 1).

\section{Results and Discussion}

\section{In vitro efficacy of bio-agents}

Among Two isolates of Trichoderma viride using dual culture technique TV-1, (JNKVV Jabalpur isolate) showed $60.22 \%$ inhibition on radial growth of $M$. phaseolina (Table 2) whereas other isolate of Trichoderma viride Tv-2, (TNAU, Tamilnadu) showed $43.18 \%$ inhibition over control. Among two isolates of Pseudomonas fluorescence testing using the dual culture technique Pf-1, (JNKVV Jabalpur isolate) showed $48.86 \%$ inhibition on radial growth on $M$. phaseoli (Table 2) whereas other isolate of Pseudomonas fluorescence Pf-2 (TNAU, Tamilnadu) showed $44.31 \%$ inhibition over control hence all tested bio agents were significant effective.

Two isolate of Trichoderma virideTv1 and Tv2 and two isolates of Pseudomonas fluorescensPf1 and Pf2 were tested for the antagonistic effect against $M$. phaseolina by dual culture method. The native isolate Tv1 and pf1 (JNKVV Jabalpur) Trichoderma viride and Pseudomonas fluorescens was found most effective in inhibiting the radial growth $(60.22 \%)$ and $(48.86 \%)$. Significant antagonistic property of Trichoderma viride against $M$. phaseolina has been reported by many workers (Deshmukh and Raut (1992), Sindhan et al., (2002) and Karthikeyan et al., (2006), Anju and Verma (2007)). Jeyarajan (1996) reported that Trichoderma isolate also reduced the number and size of sclerotia as observed in the present investigation. Native isolate was most effective and has not been reported so far hence, seems to be the first report in this aspect. The antagonistic effect of Trichoderma spp. against $M$. phaseolina also has been reported by Parakhia and Vaishnav (1986). The present findings were in consonance with the results of Ahmad and Shrivastava (2000); Vyas and Patel (2015) as 
they reported that $T$. virid eand B. subtilis were effective against $M$. phaseolina causing dry root rot of chickpea. Similar result was also found by Khirood and Paramjit (2012) while working with $M$. phaseolina. Zape et al., (2014) recorded that Trichoderma spp. was very effective in inhibiting the mycelial growth and sclerotial production of $M$. phaseolina and Singh and Verma (2015) also achieved effective growth inhibition of $M$. phaseolina by using bacterial bioagents $B$. subtilis.

Table.1 Detailed of the treatments were included

\begin{tabular}{|l|l|}
\hline $\mathrm{T}_{1}$ & $\begin{array}{l}\text { Seed treatment } T . \text { viride } 10 \mathrm{~g} / \mathrm{kg}+\text { soil application of } T \text {.viride } 2.5 \mathrm{Kg} / \mathrm{ha} \\
\text { enriched in } 100 \mathrm{Kg} \text { of FYM at sowing. }\end{array}$ \\
\hline $\mathrm{T}_{2}$ & $\begin{array}{l}\text { Seed treatment } P \text {. fluorescens } 10 \mathrm{~g} / \mathrm{kg}+\text { Soil application of } P \text {. fluorescens } 2.5 \\
\text { Kg/ha enriched in } 100 \mathrm{Kg} \text { of } \mathrm{FYM} \text { at sowing. }\end{array}$ \\
\hline $\mathrm{T}_{3}$ & $\begin{array}{l}\text { Seed treatment } T . \text { viride } 10 \mathrm{~g} / \mathrm{kg}+\text { soil application of } T . \text { viride } 2.5 \mathrm{Kg} / \mathrm{ha} \\
\text { enriched in } 100 \mathrm{Kg} \text { of } \mathrm{FYM}+\text { Oil cake @ } 250 \mathrm{~kg} / \mathrm{ha} \text { at sowing. }\end{array}$ \\
\hline $\mathrm{T}_{4}$ & $\begin{array}{l}\text { Seed treatment } P . \text { fluorescens } 10 \mathrm{~g} / \mathrm{kg}+\text { soil application of } P . \\
\text { fluorescens } 2.5 \mathrm{Kg} / \mathrm{ha} \text { enriched in } 100 \mathrm{Kg} \text { of } \mathrm{FYM}+\text { Oil cake } 250 \\
\mathrm{~kg} / \mathrm{ha} \text { at sowing. }\end{array}$ \\
\hline $\mathrm{T}_{5}$ & $\begin{array}{l}\text { Seed treatment } T . \text { viride }+P . \text { fluorescens } 10 \mathrm{~g} / \mathrm{kg}+\text { Soil application of } P . \\
\text { fluorescens } @ 2.5 \mathrm{Kg} / \mathrm{ha}+T . \text { viride } 2.5 \mathrm{Kg} / \mathrm{ha} \text { enriched in } 100 \mathrm{Kg} \text { of FYM }+ \\
\text { Oil cake @ } 250 \mathrm{~kg} / \mathrm{ha} \text { at sowing. }\end{array}$ \\
\hline $\mathrm{T}_{6}$ & Seed treatment with Thiram $2 \mathrm{~g} / \mathrm{kg}+$ Carbindazim $1 \mathrm{~g} / \mathrm{kg}(2: 1) 0.3 \%$. \\
\hline $\mathrm{T}_{7}$ & Untreated check. \\
\hline
\end{tabular}

Table.2 Effect of the bio agents against Macrophomina phaseolina by Dual Culture technique

\begin{tabular}{|l|l|l|l|l|}
\hline Treatments & Bio-agents & Source & $\begin{array}{l}\text { Mean colony } \\
\text { diameter }(\mathbf{m m})\end{array}$ & $\begin{array}{l}\text { Percent } \\
(\mathbf{\%})\end{array}$ \\
\hline T1 & $\begin{array}{l}\text { Trichoderma } \\
\text { viride }(T v-1)\end{array}$ & $\begin{array}{l}\text { JNKVV., } \\
\text { Jabalpur }\end{array}$ & 35 & 60.22 \\
\hline T2 & $\begin{array}{l}\text { Pseudomonas } \\
\text { fluorescence } \\
\text { (Pf1) }\end{array}$ & $\begin{array}{l}\text { JNKVV., } \\
\text { Jabalpur }\end{array}$ & 45 & 48.86 \\
\hline T3 & $\begin{array}{l}\text { Trichoderma } \\
\text { viride (Tv-2) }\end{array}$ & $\begin{array}{l}\text { TNAU } \\
\text { (Tamilnadu) }\end{array}$ & 50 & 43.18 \\
\hline T4 & $\begin{array}{l}\text { Pseudomonas } \\
\text { fluorescence } \\
\text { (Pf2) }\end{array}$ & $\begin{array}{l}\text { TNAU } \\
\text { (Tamilnadu) }\end{array}$ & 49 & 44.31 \\
\hline T5 & Control & & 88 & \\
\hline S. Em \pm & CD at $(\mathrm{P}=0.05 \%)$ & 0.57 & \\
\hline
\end{tabular}


Table.3 Field performances of various bio-control agents on root rot, yield and B.C. ratio

\begin{tabular}{|c|c|c|c|}
\hline Treatment & $\begin{array}{l}\text { Root and stem } \\
\text { rot incidence } \\
(\%)\end{array}$ & $\begin{array}{c}\text { Yield } \\
\text { (kg/ha) }\end{array}$ & $\begin{array}{l}\mathrm{B}: \mathrm{C} \\
\text { ratio }\end{array}$ \\
\hline $\begin{array}{l}\text { T1-Seed treatment } T \text {. viride@ } 10 \mathrm{~g} / \mathrm{kg}+\text { soil application of } \\
T \text {. viride@ } 2.5 \mathrm{~kg} / \mathrm{ha} \text { enriched in } 100 \mathrm{~kg} \text { of FYM at } \\
\text { sowing. }\end{array}$ & $20.5(26.89)$ & $\begin{array}{c}312.77 \\
(312.73)\end{array}$ & 1.23 \\
\hline $\begin{array}{l}\text { T2-Seed treatment } P . \text { fluorescens } @ 10 \mathrm{~g} / \mathrm{kg}+\text { Soil } \\
\text { application of } P . \text { fluorescens } @ 2.5 \mathrm{~kg} / \mathrm{ha} \text { enriched in } 100 \\
\mathrm{~kg} \text { of FYM at sowing. }\end{array}$ & $26.6(31.03)$ & $\begin{array}{c}268.9 \\
(268.96)\end{array}$ & 0.75 \\
\hline $\begin{array}{l}\text { T3-Seed treatment } T \text {. viride@ } 10 \mathrm{~g} / \mathrm{kg}+\text { soil application of } \\
T . \text { viride@ } 2.5 \mathrm{~kg} / \mathrm{ha} \text { enriched in } 100 \mathrm{~kg} \text { of FYM + Oil } \\
\text { cake) @ } 250 \mathrm{~kg} / \mathrm{h} \text { at sowing. }\end{array}$ & $14(21.96)$ & $\begin{array}{c}385.4 \\
(385.4)\end{array}$ & 1.77 \\
\hline $\begin{array}{l}\text { T4-Seed treatment P. fluorescens@ } @ 10 \mathrm{~g} / \mathrm{kg}+\text { soil } \\
\text { application of } P . \text { fluorescens@ } 2.5 \mathrm{~kg} / \mathrm{ha} \text { enriched in } 100 \\
\mathrm{~kg} \text { of FYM + Oil cake) @ } 250 \mathrm{~kg} / \mathrm{ha} \text { at sowing. }\end{array}$ & $28(31.93)$ & $\begin{array}{c}287.2 \\
(287.26)\end{array}$ & 0.82 \\
\hline $\begin{array}{l}\text { T5-Seed treatment } T . \text { viride }+P . \text { fluorescens } @ 10 \mathrm{~g} / \mathrm{kg}+ \\
\text { Soil application of } P . \text { fluorescens@ } 2.5 \mathrm{~kg} / \mathrm{ha}+T . \text { viride@ } \\
2.5 \mathrm{~kg} / \mathrm{h} \text { e enriched in } 100 \mathrm{~kg} \text { of FYM + Oil cake) @ } 250 \\
\mathrm{~kg} / \mathrm{ha} \text { at sowing. }\end{array}$ & $12.3(20.45)$ & $\begin{array}{c}402.23 \\
(402.23)\end{array}$ & 1.81 \\
\hline $\begin{array}{l}\text { T6-Seed treatment } T \text {. viride }+P \text {. fluorescens @ } 10 \mathrm{~g} / \mathrm{kg}+ \\
\text { Soil application of P. fluorescens @ } 2.5 \mathrm{~kg} / \mathrm{ha}+T \text {. viride } \\
@ 2.5 \mathrm{~kg} / \mathrm{ha} \text { enriched in } 100 \mathrm{~kg} \text { of FYM + Oil cake) @ } \\
250 \mathrm{~kg} / \mathrm{ha} \text { at sowing. }\end{array}$ & $16.5(23.95)$ & $\begin{array}{c}380.63 \\
(380.63)\end{array}$ & 1.71 \\
\hline T-7 Untreated check & \multicolumn{2}{|l|}{$37.1(37.5)$} & 133.33 \\
\hline S.Em \pm & \multicolumn{2}{|l|}{4.03} & 1.71 \\
\hline $\mathrm{CD}$ at $(\mathrm{P}=0.05 \%)$ & \multicolumn{2}{|l|}{11.34} & 3.06 \\
\hline $\mathrm{Cv}$ at $(5 \%)$ & \multicolumn{2}{|l|}{1.98} & 9.44 \\
\hline
\end{tabular}

\section{In vivo efficacy of bio-agents}

Data Presented in (Table 3) reveal that all tested treatments were significantly effective and highly seed yield over, T5-Seed treatment with $T$. viride + P. fluorescence @ $10 \mathrm{~g} / \mathrm{kg}+$ Soil application of $P$. fluorescence @ 2.5 $\mathrm{kg} / \mathrm{ha}+T$. viride @ $2.5 \mathrm{~kg} / \mathrm{ha}$ enriched in 100 $\mathrm{kg}$ of FYM + Oil cake) @ $250 \mathrm{~kg} / \mathrm{ha}$ at sowing recorded minimum disease incidence $(12.3 \%)$, maximum yield $(402.23 \mathrm{~kg} / \mathrm{ha})$ and Benefit cost ratio (1.81) followed by Treatment T3-Seed treatment T. viride@ $10 \mathrm{~g} / \mathrm{kg}+$ soil application of T. viride @ 2.5 $\mathrm{kg} / \mathrm{ha}$ enriched in $100 \mathrm{~kg}$ of FYM + Oil cake) ( $250 \mathrm{~kg} / \mathrm{ha}$ at sowing recorded minimum disease incidence (14\%) maximum yield $(385.4 \mathrm{~kg} / \mathrm{ha})$ cost benefit ratio 1.77 over control.

Field performance of Effective biocontrol agent under field condition was studied during 2017-2018.The result indicated that all the treatment had higher germination performance as compared to control treatment T5 (Seed treatment $T$. viride+ P. fluorescence @ $10 \mathrm{~g} / \mathrm{kg}+$ Soil application of $P$. fluorescence@2.5 kg/ha +T. viride@2.5 $\mathrm{kg} / \mathrm{ha}$ enriched in $100 \mathrm{~kg}$ of FYM + Oil cake @ $250 \mathrm{~kg} / \mathrm{ha}$ at sowing respectively) recorded minimum incidence $(12.3 \%)$, maximum yield $(402.23 \mathrm{~kg} / \mathrm{ha})$ and higher Benefit cost 
ratio1.81 followed by T3 (Seed treatment $T$. viride @ $10 \mathrm{~g} / \mathrm{kg}$ + soil application of T. viride @ $2.5 \mathrm{~kg} / \mathrm{ha}$ enriched in $100 \mathrm{~kg}$ of FYM + Oil cake) @ $250 \mathrm{~kg} / \mathrm{ha}$ at sowing) recorded minimum incidence (14\%) maximum yield (385.4 kg/ha) and cost benefit ratio 1.77 over control. Kheri and Chandra (1991) recorded that $T$. konigii was inhibitory effect against dry root rot of mung caused by $M$. phaseolina. Chung and Choi, (1990) also observed that $T$. viride, $T$. harzianum and $B$. subtilis have strong biocontrol effect against Macrophomina phaseolina causing stem and root rot in sesame. Afouda et al., (2012) in cowpea against root rot (M. phaseolina) pathogen in field, who reported that $B$. subtilis showed strongest antagonistic activity against M. phaseolina. In the field experiment seed treatment and soil application of $T$. viride reduced the incidence of root and stem rot. The present result is in accordance with reports of Dinakaran et al., (1995), Sanker and Jeyarajan (1996), Nair et al., (2006).Gupta et al., (2016).

In conclusion the efficacy of bioagentsTv-1 and $\mathrm{pf}_{1}$ (JNKVV Jabalpur isolate) showed maximum inhibition on radial growth of $M$. phaseolina. Field performance of bioagents ware found significantly effective and higher seed yield. Treatment $\mathrm{T}_{5}$-Seed treatment $T$. viride + P.fluorescence @ $10 \mathrm{~g} / \mathrm{kg}+$ Soil application of $P$. fluorescence @ $2.5 \mathrm{~kg} / \mathrm{ha}+$ T.viride@2.5 kg/ha enriched in $100 \mathrm{~kg}$ of FYM + Oil cake)@250 kg/ha at sowing was recorded minimum disease incidence $(12.3 \%)$,maximum yield $(402.23 \mathrm{~kg} / \mathrm{ha})$ and Benefit cost ratio (1.81) followed by Treatment $\mathrm{T}_{3}$-Seed treatment $T$. viride @ $10 \mathrm{~g} / \mathrm{kg}+$ soil application of T. viride @ 2.5 $\mathrm{kg} / \mathrm{ha}$ enriched in $100 \mathrm{~kg}$ of FYM + Oil cake) @ $250 \mathrm{~kg} / \mathrm{ha}$ at sowing recorded minimum disease incidence (14\%) maximum yield (385.4 kg/ha) and cost benefit ratio 1.77 over control.

\section{Acknowledgement}

The authors express thanks to Department of Plant Pathology, College of Agriculture, Jabalpur, Jawaharlal Nehru Krishi Viswavidlaya, Jabalpur for providing all the facilities to conduct work.

\section{References}

Afouda, L.C.A., Schulz, D., Wolf, G. and Wydra, K. 2012.Biological control of Macrophomina phaseolina on cowpea (Vigna unguiculata L.) under dry conditions by bacterial antagonists. Int. J. Biol. Chem.

Ahmad, S., and Shrivastava, M. 2000.Biological control of dry root rots of chickpea with plant products and antagonistic microorganism. Ann. Agric. Res. 21(3):450-451. 451

Anju, G., and Verma, R.K. 2007.Non-target effect of agro-chemicals and Bio-controls agents on important soil-borne pathogen of Soybean. JNKVV Res. J. 4; (1): 65-71.

Anonymous, 2017.Annual Report. ICAR All India Coordinated Research Project on Sesame and Niger, JNKVV. Jabalpur $\mathrm{p} 2$.

Avila, J., O., Aponte, J., Pineda, and Colmenares. 1999. The cultivation of sesame. FONAIAP Publication series, Araure Venezuela. Centre of lnvestigaciones of Portuguesa state 83.

Chung, H.S., and Choi, W.B. 1990.Biological control of sesame damping off in the field by coating seeds with antagonistic Trichoderma viride. Seed Tech.18: 451459.

Das, I.K., B.,Fakrudia, and Arora, D.K. 2008. RAPD cluster analysis and chlorate sensitivity of some Indian isolates of Macrophomina phaseolina from sorghum and their relationships with Pathogenicity. Microbial. Res., 163:215-224.

Deshmukh, D.P., and Raut, J.G. 1992. Antagonism by Trichoderma sp. on five plant pathogenic fungi. New Agriculturist, 3(2): 127-130.

Dinakaran, D., and Mohammed, N. 2001.Identification of resistant sources to 
root rot of sesame caused by Macrophomina phaseolina (Tassi.) Goid. Sesame and Safflower Newsletter, 16: 6871.

Dinakaran, D., Ramakrishna, D., Sridhar, R., and Jeyarajan, R. 1995. Management of sesamum root rot with biocontrol agents. J. Oilseeds Res. 12(2): 262-263.

Gupta, K.N. 2016. Integrated management of Charcol rot (Macrophomina phaseolina) of Sesame. Bioinfolet, 13 (1A) 43-44.

Gupta, K.N., Naik, K.R. and Bisen, R. 2018.Status of sesame diseases and their integrated management using indigenous practices. International Journal of Chemical Studies. 6(2): 1945-1952.

Karthikeyan, V., Sankaralingam, A., and Nakkeeran, S. 2006. Management of groundnut root rot with biocontrol agents and organic amendment. Archives of Phytopath. Pl. Protec. 39(3): 215 - 223.

Karthikeyan, V., Sankaralingam, A., and Nakkeeran, S. 2006. Management of groundnut root rot with biocontrol agents and organic amendment. Archives of Phytopath. Pl. Protec. 39(3): 215 - 223.

Khirood, D., and Paramjit, K.J. 2012. In vitro efficacy of Trichoderma viride against Sclerotiumrolfsii and Macrophomina phaseolina. Sci. Biol. 4(4): 39-44.

Maiti, S., Hedge, M.R., and Chattopadhyay, S.B. 1988.Handbook of Annual Oilseed Crops.Oxford and IBH Publ. Co. Pvt. Ltd., New Delhi.

Menezes, M., and Oliveira, S.A. 1993. Fungosfitopatogenicos. Recife: UFRPE, 277.

Mukharji, K.G., and Bhasin, J. 1986. Plant disease in India. Today and Tomorrow Publisher. New Delhi.

Parakhia, A.M., and Vaishnav, M.U. 1986.
Biocontrol of Rhizoctonia bataticola. Indian Phytopath.39(3): 439.

Rajput, M.A., Khan, Z.H., Jafr, K.A., and FazalAli, J.A. 1998.Field screening of sesame germplasm for resistance against charcoal rot (Macrophomina phaseolina). Sesame and Safflower Newsletter, 13: 63-66

Sagar, V., and Sugha,S.K. 1997. Role of individual and combine inoculation on the development pea root rot. Indian Phytopathology. 50: 499-50.

Sankar, P., and Jeyarajan, R. 1996. Biological control of Sesamum root rot by seed treatment with Trichoderma $\mathrm{sp}$. and Bacillus subtitles'. Indian Journal of Mycology and Plant Pathology. 26(2): 217-220.

Sindhan, G.S., Hooda, I., and karwasra, S.S. 2002. Biological control of dry root rot of chickpea caused by Rhizoctonia bataticola. Pl. Dis. Res. 17(1): 68-71.

Singh,G., and Verma, R.K. 2015.Compatibility of bioagents and neem products against root rot of soybean. J. Mycopatho. Res. 43(2): 211-214.

Vincent, J.M. 1947. Distortion of fungal Hyphae in the presence of certain inhibitor. Nature 159-850.

Vyas, S.C. 1981. Diseases in Sesamum in India and their control. Pesticides, 15: 10

Vyas, S.C., and Patel, M.C. 2015.Integrated biological and chemical control of dry root rot of chickpea. Indian J. Mycol. Pl. Pathol.24(2):132-34

Zape, A.S., Gade, R.M., Singh, R., and Deshmukh, V.A. 2014. Efficacy of different antagonist against the Sclerotium rolfsii, Rhizoctonia solani and Fusarium solani. International Journal of Life Sciences. 9(4): 1431-1434.

\section{How to cite this article:}

Jainpal Rathore, K. N. Gupta, Babli Verma and Gunnjeet Kaur. 2020. Evaluation of Bio-control Agents against Macrophomina phaseolina Causing Root and Stem Rot Disease of Sesamum. Int.J.Curr.Microbiol.App.Sci. 9(09): 411-417. doi: https://doi.org/10.20546/ijcmas.2020.909.052 